\title{
Daughter-Father Relationships. Biographical Research from a Feminist Perspective
}

\begin{abstract}
This article aims to contribute to the debate about the reflection on biographical experiences, in particular, the relationship between daughter and father. It presents my research project devoted to young adult women, students, and their perceptions of their relationships with fathers. It also contains an analysis of autobiographical essays of female students (the research participants). The main idea of this research is to appreciate the women's points of view and to underline the role of reflexivity in the constitution of self-knowledge. Also, I try to discuss my process of becoming a reflective feminist researcher.
\end{abstract}

Keywords: daughter, father, biographical experience, feminist methodology, reflexivity.

\section{Relacja córka - ojciec. Badania biograficzne w perspektywie feministycznej}

\begin{abstract}
Abstrakt
Niniejszy artykuł jest skromnym przyczynkiem do debaty na temat refleksji nad doświadczeniami biograficznymi, w szczególności dotyczącymi relacji między córką a ojcem. W artykule omawiam przeprowadzony projekt badawczy poświęcony młodym kobietom, studentkom oraz ich postrzeganiu relacji córki z ojcem. Analizie poddaję autobiograficzne eseje kobiet studentek, uczestniczek projektu. Główną ideą tych badań jest dowartościowanie punktów widzenia samych kobiet oraz podkreślenie roli refleksyjności w procesie rozwijania samoświadomości. $\mathrm{W}$ tekście próbuję również przyjrzeć się własnemu procesowi stawania się refleksyjną badaczką feministyczną.
\end{abstract}

Słowa kluczowe: córka, ojciec, doświadczenie biograficzne, metodologia feministyczna, refleksyjność.

\footnotetext{
* Uniwersytet Warszawski, Instytut Profilaktyki Społecznej i Resocjalizacji, Katedra Pedagogiki Społecznej.
} 


\section{Rationale}

In 2011 I started an experimental research project which I entitled "Daughterfather relationships in autobiographical texts". It was directed exclusively to young, adult women, aged from 19 to 23. They were students of first degree studies at the University of Warsaw. Their task was to write an autobiographical essay about their relationships with their fathers. The basic aim of the research was to answer the question: how do women perceive their relationships with their fathers. I was interested in how women talk about themselves and their biographical experiences. Who is a father for an (adult) daughter? What kind of role does a father have in the process of her self-construction? What memories and emotions does the reflection on their biography emerge? Those questions were followed by other questions, the ones about my role in the research.

From the beginning of the project, I advocated for the feminist and feminine points of view. The reflection on the relationship between daughter and father was not to affirm a father (male) figure in a daughter's (woman's) life. My intention was to analyse different biographical experiences of women and emphasize women's points of view.

The research project lasted during the summer semester of 2011. As a result, I collected 20 essays. I decided to discuss three of them in this article.

\section{Feminist Methodology}

Feminist studies are focused on women. They problematize the different situations/experiences of women. Their goal is to create equal opportunities for women to express themselves and to participate in academic, social and political life. The accent is on what women have to say. The exploration and understanding of the meanings which women assign to their experiences is the main research aspiration for feminist methodology (Maynard 1995). On the other hand, the question about the category of woman is an important issue in feminist studies. What does the term woman actually mean? A biological sex, or set of certain features assigned to women? On whose behalf am I actually speaking, and whether - as a feminist researcher - I can speak on behalf of (all) women?

The claim that (all) women form one community (on account of the gender) and that they share the same social position, which can be put through an examination by an understanding researcher (also a woman) is incorrect. Women do not have the same experiences and they do not constitute the uniform subjectivity. The fact that studies are done by women and with the participation of women could not be the distinctive feature of feminist research. Gender does not guarantee access to women's knowledge and life (Olesen 2005: 248). The issue is not to ignore the differences that exist among women. These differences refer both to women's 
individual experiences, as well as different social and cultural features (social class, ethnicity, etc.). Feminist studies focus therefore on the exploration and analysis of the reality of the position of an individual or a group with a strong emphasis on the diversity of biographical experiences. As a result, feminist reflections offer a variety of ways to describe the differences, as Ilene Alexander clearly highlights, "differences", not "divisions" (Alexander 1989: 100). Hence the recognition of the different experiences of different women is an aim of feminist methodologies.

\section{Standpoint Theories}

One of the approaches developed within feminist methodology and epistemology is standpoint theory. It emphasizes women's experience and is focused on understanding the women's point of view. The key concept of the standpoint theory is the idea of situated knowledges. According to Donna Haraway, knowledge is situated in a concrete time and place and in particular biographical experience. Knowledge is always partial, affected by someone's social location and power relations. Therefore universal or value-free knowledge is impossible (Haraway 1991).

Standpoint theory reemerged in the 1970s and 1980s as a feminist epistemology, philosophy of science, sociology of knowledge and methodology (Harding 1987: 182; Harding 1991: 105-137). It refers to the Marxist thesis of epistemological dominance of knowledge deriving from the downtrodden class; in this case, women are the downtrodden class. Drawing attention to women's (located and embodied) experiences, feminist researchers want to acquire knowledge of a woman's location in social space. This location is connected with women's age, nationality, race, family status, level of education etc.

According to standpoint theory, what we know about ourselves and others, a kind of filter through which we perceive reality, is explicitly determined by our social positions/locations. And our perceptions are influenced by many different factors, such as power relations. Therefore, from the feminist perspective social research is about revealing the contexts of social positions, especially those areas which so far have been omitted, distorted or invisible in a discourse (Harding 1986).

What is important, there is not one feminist standpoint theory but rather feminist standpoints. Harding popularized standpoint theory by referring to the work of other feminist authors. One of them is Dorothy Smith $(1987,1990,2005)$. By "standpoint" Smith means that what one knows is affected by one's subjective experience. In other words, is conditional upon the location in society (Appelrouth, Edles 2008: 585; Smith 1997). We cannot look at the world in any way other than our given standpoint. Therefore, as Smith claims, no two people have exactly the same standpoint and no one can have complete, objective knowledge. Another conclusion is that we should not take the standpoint from which we speak for 
granted. Instead, everyday experience should serve as a "point of entry" of investigation; we should recognize it, be reflexive about it, and problematize it (Appelrouth, Edles 2008: 585; Smith 2005: 10).

Patricia Hill Collins also contributes to the standpoint theory. She draws on black women's experiences and voices particularly (1990, 2004, 2005). Collins focused on Smith's critical/phenomenological feminist ideas by "illuminating how race is intertwined with gender and class" (Appelrouth, Edles 2008: 607). In her opinion our stand of domination is made up of race, class, gender, nationality, sexual orientation.

In this paper I use standpoint theory in two ways. First of all, as an interpretive strategy to anchor the meaning of the essays within feminist context. Further, I use standpoint theory as an epistemological framework for recognizing my own personal involvement in the research. My position in the research could be described as an insider-outsider. As a researcher I am in a position of outsider. Also as a researcher I am in a position of power. It is mainly me who interprets the collected essays, selects them and makes the decisions about what and how to write. But at the same time I am in a position of insider - I am a woman and a daughter. Being aware of these two roles, my personal involvement in the project, I am able to recognize my views and bias and recognize how they could shape the research.

As a woman and a daughter I share a common location in the social world with the participants on the basis of our sex and gender. But it does not guarantee similar experiences. Different women mean different stories and different experiences. Although I am a woman and a daughter, my social location is different as well as my point of view on the subject of this study. I am different from the womenparticipants not only because of my age, level of education or position the university, but also because of my position in this project.

\section{Data}

In this paper I decided to focus on the discussion of three selected essays. In order to analyze them, I adopted a method of qualitative data analysis. The basis of the system of categorization is the text of the essays. I derived two main categories from them: "daughter" and "father". I expanded each of them on the basis of a list of subcategories. Also I emerged the main category for each of the essays (daughter or father). This category brings together all the elements of the text and develops the narrative.

In order to structure the content of the essays, I distinguished three main textual dimensions:

- problems - what the subject of the reflection is, and how the individual author narrates about herself and her relationship with her father (rhetoric, metaphors, explanations); 
- the temporal dimension - the scope of the biography subjected to the reflection; the time perspective included in the essay (the past, the present and the future);

- dimensions of reflexivity - personal dimension and social dimension.

\section{Presentation of the essays}

\section{Essay 1, Who Am I? (student in her third year of bachelor's studies)}

My experience shows that the best thing to find myself was the feeling of pleasure in self-development and learning who I am.

The central theme of the essay is the broken relationship with a father. Selfidentification of the author ${ }^{1}$ follows through a refusal to identify with her father. She accepts the lack of this relationship. The author presents a negative image of her father.

There are two parts of the essay. In the first part the author focuses on the presentation of herself and what her "now" is; and the second part of the essay is a general reflection about relationships and building an emotional bond among people.

The author does not provide any information about her father, such as age, profession or occupation. She presents her father with the words "suffering from alcoholism". There are no other words about her father. It seems that the short description "suffering from alcoholism" contains everything that the author says about her father. She describes him through his alcoholism. She writes, "What is my father like? My reply is: angry, unhappy, sick, aggressive and weak." Later she admits, "He was not and will never be good in my eyes".

Another issue is the author's refusal to identify with her father. She writes, "The role of my father in my life does not matter, I do not want a father, I do not want my father". The author admits that she is aware of rejecting this relationship. She admits that she is reconciled with herself after the decision. That relationship is said to be "a relationship that never existed".

In the author's opinion there has been a lack of communication with her father. She does not know who she is for her father; she writes, "I do not know who I was for my father".

When she writes about herself, she refers to being her mother's daughter, not her father's. She describes herself as a woman, a student, a friend, a sister and her mother's daughter. The author sees herself as an adult person. She writes, "I'm an

\footnotetext{
1 In all three essays I decided to use the form "author" instead of "authoress".
} 
adult, I am myself, I feel free and I feel free to decide for myself, I have a right to happiness".

She focuses on the present. The present is synonymous with the adulthood, self-knowledge, self-development and so on. She writes, "I have known a lot about what I was like in the past. And I know what I am now". She finds herself out of a relationship with her father; she writes, "I am reconciled with the fact that he is not here, I do not want a father, I do not surrender to the social coercion to love my father". The author writes about a sense of relief. According to her, there are no bad emotions.

In the second part of the essay the term "family trap" appears, which becomes a motif of reflection on the phenomenon of social coercion to love parents. The author does not agree to be bound by the social compulsion to love her parents. In her view, "We love others for something". She comes to the conclusion that people cannot create a relationship - "real, healthy relationship" - if they are forced to love someone. In her opinion, the bonds of blood are not a sufficient condition to establish an emotional bond within the family. She contrasts relationships based on sincerity with the ones based on coercion. She believes in honest, voluntary and free love.

\section{Essay 2, Father's True Daughter (student in her third year of bachelor's studies)}

\section{On the other hand, I cannot imagine my life without him.}

The author's self-identification is accomplished by comparing herself with her father. The essay begins and ends with descriptions of an epiphany. At the beginning the author mentions the funeral of her grandfather and that event becomes a stimulus to a reflection on "what would happen if my father died". The author comes to the conclusion that regardless of the nature of her relationship with her father, his death would be a hard experience for her. She admits that she is not able to imagine that she could live without him.

At the end of the essay the author recalls a memory which also can be described as a kind of biographical epiphany. Deeply moved, the author writes about the (unexpected) gift she received surprisingly from her father. The memory of that event makes her cry ("I have tears in my eyes").

The main category of the essay is father (dad). The author does not give any information about her father's age and occupation. She writes that he worked in the hospital and gained "extensive and comprehensive education". She remembers that when she was a child, her father was often absent at home. She missed him. She writes, "I saw my dad just a few minutes a day". She took advantage of every opportunity to visit her father in the hospital where he worked (she used to go to the hospital by bicycle). 
Now she has "ambivalent emotions towards her dad". She admits that nowadays there is a sense of anxiety and frustration because of her father being all the time at home. "A huge shock" - that is what she writes about her father's change of lifestyle. His presence at home means the collapse of the (slow) rhythm of everyday life, which the author used to know in the past. It is a source of anxiety and conflicts about "the little things". The author admits that it is difficult to talk with her father "about things other than the daily affairs". She explains that there are difficulties in the communication "because of her resemblance to her father".

Her father is a "unique figure" for the author. She has the feeling that in spite of many efforts she cannot be the equal (and will never be the equal) of her father in the professional achievements ("it does not work").

The author compares herself with her father. She uses the words "my father's true daughter". She notices some similarity to him, but also she is aware of the differences which she shares with her father. She says that unlike him she is "much more conciliatory and easygoing". She thinks the resemblance to her father is a major cause of the difficulty in communicating with him.

\section{Essay 3, [no title] (student in her third year of bachelor's studies)}

\section{I don't have an explicit answer to the question about who I am}

The author presents a positive image of her father. She accomplishes selfidentification through the process of self-awareness of the transformation from the "little girl" into an "adult woman".

The main category of the essay is father (dad, daddy). The author writes that her father owned a sawmill, worked as a bricklayer, and now he is working abroad, and he often travels. There is no information about the type of work he is performing nowadays.

The author admits that in the past, "I wanted to be like my daddy". She spent a lot of time with her father. She writes, "At the age of five I followed my father everywhere". She lists a number of her father's virtues: hardworking, resourceful, kind etc. She admires her father. As far as work is concerned, the author's father is a model for her. She defines him as a "head of the family". The author writes that her father thinks of himself as "the guardian of the family". She says, "My father always feels (and will always feel) the pressure and obligation to care for our family".

The author is proud of her father. His attitude to work and people (helping others) had a deep impact on the field of study chosen by the daughter.

She admits that the quality of communication with her father is now getting worse. She writes, "Now we are spending less and less time with each other, and the gap between us is growing". The author writes that her expectations as an adult 
person are different from the expectations of the little girl that she used to be. She assumes that her father does not notice these changes.

She claims that she is like her father, "I am the father's daughter". Although she is no longer a "little girl," she is still in the position of a child. She admits that she often asks herself the question of who she is. But the answer to this question is difficult for her. She writes that she can say who she is only in the context of "here and now". She describes herself, "I am a child, a daughter, a sister, a student, a person, a friend".

The author has positive memories from her childhood and recalls them willingly. She talks about spending time together with her father, playing with him and learning from him. Generally speaking, her childhood appears to be a happy and successful period in her life. The author regrets that the time spent with her father (fishing and hiking together, or listening to his stories) is already a thing of the past.

An important part of the essay is a reflection on the daughter's expectations towards her father, and the ideas associated with having children and being a mother. She writes, "I want my children to believe that their opinions matter and that they are able to have a friendly relationship with their parents".

Below, there is a table containing selected quotes of the authors' views and statements from three essays. These quotes are divided in two main categories: "father" and "daughter".

Table 1. The authors' views and statements by major categories: "father" and "daughter (about herself)"

\begin{tabular}{|c|c|c|c|}
\hline & Essay 1 & Essay 2 & Essay 3 \\
\hline FATHER & $\begin{array}{l}\text { - Suffering from } \\
\text { alcoholism } \\
\text { - Poor, miserable, } \\
\text { sick, aggressive and } \\
\text { weak } \\
\text { - In my eyes he was } \\
\text { not and will never be } \\
\text { good } \\
\text { - A father figure does } \\
\text { not matter in my life } \\
\text { - I feel I am not my } \\
\text { father's daughter } \\
\text { - I do not want a } \\
\text { father. }\end{array}$ & $\begin{array}{l}\text { - I have very ambivalent } \\
\text { emotions towards my } \\
\text { dad } \\
\text { - On the one hand, he is } \\
\text { a role model of mine } \\
\text { - I would like to have the } \\
\text { qualifications he has } \\
\text { - I had rather poor } \\
\text { contact with my father } \\
\text { - I do not remember my } \\
\text { father being at home in } \\
\text { my childhood } \\
\text { - A bad-tempered man } \\
\text { - It is good when my dad } \\
\text { is not at home. [...] No } \\
\text { one quarrels about the } \\
\text { little things }\end{array}$ & $\begin{array}{l}\text { - I wanted to be like } \\
\text { Daddy } \\
\text { - My father has } \\
\text { always been an } \\
\text { authority for me } \\
\text { - He is resourceful, } \\
\text { talented and kind } \\
\text { - Father is a bricklay- } \\
\text { er by profession } \\
\text { - He is active and } \\
\text { hard-working } \\
\text { - I would like to learn } \\
\text { from him } \\
\text { - It is sometimes hard } \\
\text { for my father to } \\
\text { understand that from } \\
\text { the little girl I grew }\end{array}$ \\
\hline
\end{tabular}




\begin{tabular}{|c|c|c|c|}
\hline & & $\begin{array}{l}\text { - On the other hand, I } \\
\text { cannot imagine my life } \\
\text { without him. }\end{array}$ & $\begin{array}{l}\text { into an adult woman } \\
\text { and he needs to talk to } \\
\text { me differently than in } \\
\text { the past } \\
\text { - I am proud that I am } \\
\text { my father's daughter } \\
\text { - He is the head of our } \\
\text { family } \\
\text { - My father always } \\
\text { feels and will always } \\
\text { feel the pressure and } \\
\text { obligation to care for } \\
\text { our family. }\end{array}$ \\
\hline DAUGHTER & $\begin{array}{l}\text { - My mother's } \\
\text { daughter, not my } \\
\text { father's } \\
\text { - Daughter of an } \\
\text { alcoholic } \\
\text { - A woman, a student, } \\
\text { a friend, a sister, my } \\
\text { mother's daughter } \\
\text { - I am adult } \\
\text { - I am myself } \\
\text { - I feel free and I feel } \\
\text { the freedom in making } \\
\text { my own decisions } \\
\text { - I already know quite } \\
\text { a lot about who I was. } \\
\text { I also know who I am } \\
\text { now } \\
\text { - I do not surrender } \\
\text { to the social scheme of } \\
\text { the coercion to love } \\
\text { my father. }\end{array}$ & $\begin{array}{l}\text { - My father's true } \\
\text { daughter } \\
\text { - I can finish three } \\
\text { different fields of study, } \\
\text { but it will be not enough } \\
\text { to beat my father's } \\
\text { achievements } \\
\text { - Unlike my father, I'm } \\
\text { much more willing to } \\
\text { reconcile } \\
\text { - Showing affection is } \\
\text { not so difficult for me as } \\
\text { it is for my father. }\end{array}$ & $\begin{array}{l}\text { - Everyone in my } \\
\text { family tells me that } \\
\text { my character comes } \\
\text { from my father: } \\
\text { quarrelsome, but } \\
\text { always willing to help } \\
\text { - I grew from the little } \\
\text { girl into an adult } \\
\text { woman } \\
\text { - At this moment I'm } \\
\text { still in the position of } \\
\text { a child in my family } \\
\text { - I don't have an } \\
\text { explicit answer to the } \\
\text { question about who I } \\
\text { am } \\
\text { - I am a child, a } \\
\text { daughter, a sister, a } \\
\text { student, a person, and } \\
\text { a friend } \\
\text { - I am quarrelsome, } \\
\text { sensitive, stubborn } \\
\text { and helpful } \\
\text { - I am myself. }\end{array}$ \\
\hline
\end{tabular}

\section{Analysis of the essays}

The issues I would like to discuss are related to emancipation, patriarchal family and the transformation from a girl into a woman. In each of these essays we are dealing with problems of gender stereotypes and each of the authors has a different 
attitude toward these stereotypes. Also, it seems, the relation with father affects the image of daughter and her attitude towards herself.

Emancipation is the issue that dominates in essay no. 1. The author writes from the standpoint of an adult woman who does not identify herself with her father. The experiences of being a daughter of an alcoholic do not prevail in her image of herself. Also she does not evoke any memories from childhood. She seems to be separated from her past.

This essay shows an image of a woman who is emancipated from the relation with her father. Breaking this relation was a decision made by the author consciously. The decision led her to the present state of "finding herself," a significant moment of her biography; a moment of emancipation - a relief and freedom of making decisions on her own. Expressions and phrases like "I feel/I don't feel" appear frequently in the essay (she writes that she feels she is her mother's daughter or she feels free now. She admits, "I feel a relief, and it is fine to feel that").

The image of a patriarchal family appears in essay no. 2 . This daughter-father relation is an example of a traditional one: the father is a dominant figure, and his daughter - in spite of achieving the stage of adulthood - is still a child in her father's eyes. He is the type of an authoritarian father who "is always right". As the author mentions, her father is proud of her because she is a good student and is studying two different fields of study at the same time. It seems that the daughter attracts her father's attention because of her achievements as a student. Although she is aware of ambivalent emotions towards him, she still tries to meet her father's expectations. She identifies herself with him and describes herself as "her father's true daughter". The author often uses expressions associated with memory such as "as long as I can remember", "how I remember...", "hard to forget".

The transformation of daughter, from the "little girl" into a woman, is the topic of essay no. 3. Author 3 points out that she has a strong emotional bond with her father, although now this bond is not as intensive as it was when she was a child. In her childhood the author wanted "to be like Daddy" and followed him everywhere. Now, she is a woman but her father does not notice this change - her transformation from a girl into a woman. He does not understand that she is not a child anymore ("he needs to talk to me differently"). The author defines her family as the patriarchal type: her father as "the head of the family" who "is in charge to decide". She realizes that she cannot change the nature of the relation with her father. In spite of the criticisms of her father's antifeminist views, he is an authority for her. She is proud of him. She often uses (Polish) idiomatic phrases such as "stubborn as a mule, to break the ice, or the head of the family".

\section{Dimension of time}

Each of the essays, though in a different way, includes time as a significant dimension of the authors' biographies. The present dominates essay 1 . The author focuses on what (her) now is - now she feels free and makes her own decisions. 
The present and the past appear in essay 2. It begins by recalling the recent situation - the funeral of the author's grandfather. That event evokes thoughts about the author's father. There are flashbacks and moments of biographical epiphany.

Three dimensions of time (the past, the present, the future) appear in essay 3. The author makes a holistic approach to her biography - it includes past events as well as what is now and plans for future.

\section{Dimension of reflexivity}

What is characteristic of these essays is the authors' self-awareness and reflexivity. Essay 1 is a reflection of an adult woman. She is aware that she is not a child any more. There are phrases, such as: "I am adult, I am myself, I feel free and I feel the freedom in making my own decisions". An important motif of the essay is the story about the broken relation with her father. She admits that it is not easy to love one parent and not to love the other one. What particularly emphasizes the author's reflexivity is her ability to refer to a wide social context of relations between parents and children. There is an explicit criticism of the social pressure to love your parents.

Another dimension of self-awareness appears in essay 2. Here, the leitmotif is emotional ambivalence towards father. The author describes several events (from the past and the present) that cause these ambivalent emotions. The essay is an implicit reflection on a father's influence on his daughter's life. The author compares herself with her father whom she describes as a "unique figure". In her opinion, she is not able to gain the achievements her father has. There is also a reflection on death which appears to the author as something that is "overwhelming".

Essay 3 reveals rather a different dimension of self-awareness. It is a reflection from a point of view of a daughter who is aware of the transformation she has experienced (from the little girl into an adult woman). She is also aware of the difficulty that her father is experiencing now - "It is hard sometimes for my father to understand that I grew into an adult woman and that he needs to talk to me differently than at one time". The author is critical of her father while at the same time she recognizes his virtues, which she admires. Another issue that this essay reveals is the gender stereotypes in the author's family. She perceives her father as "the head of her family," and her family as a patriarchal type. She does not see any opportunity for change in this system of family relations.

\section{Conclusions}

The reading and discussion of the essays led me to three main conclusions:

1. The presence/the absence of the father and the character of the relation between daughter and father. 
2. The father's attitude towards his daughter.

3. The daughter's growing up.

The presence, similarly to the absence of the father, can be a factor leading to misunderstandings, distance and emotional ambivalence between daughter and father. A distinct problem, which the authors of the essays reveal, explicitly and implicitly, is a lack of the (long-lasting) bond with their fathers. From the daughters' point of view, their fathers do not demonstrate their understanding and attention to:

- the right of the adult daughter to happiness (essay 1);

- the transformation of the daughter from a child into a woman (essay 3);

- the daughter's aspirations to gain individuality and autonomy (essay 2);

- the emancipation of the daughter who is subordinated to her father's ideas and expectations (essay 2 and 3).

In the case of the father's attitude towards his daughter, there is a little of knowledge about each other; author 1 even admits, "I do not know who I was for my father". In essay 2 the author feels that she will never be equal of her father, who seems to underestimate her ambitions and aspirations. Meanwhile, in essay 3, according to the author, her father does not understand the changes she has experienced (becoming an adult). She notes that her opinion is not important enough in her family to make any change in the relationship with her parents.

The facts that a daughter grows up and becomes an adult appear in all these three essays as factors that deepen the distance between the women and their fathers. The transformation of daughter - from a child into a woman - is held with the lack of father's support. Not noticing the changes in his daughter and still treating her like a child, such a father deepens the distance between them.

Feelings of distance can be also seen in the communication between daughters and fathers. In the case of essay 1 it seems there is no communication between them. The author decided to break her relation with her father. The problem is different in the case of essays 2 and 3. The daughters, now adult women, are still treated like children. The author of essay 2 admits that it is hard for her to talk to her father "about things different from everyday matters," and the author of essay 3 writes that she would like to talk to her father about many issues and share her experiences with him.

It seems that only in the case of essay 1 the author is not in the position of a child. The author's attitude is the attitude of emancipation. She is a decisionmaker - it was her decision not to accept the father who is an alcoholic.

The next two essays reveal other attitudes. These authors are not able to set and maintain their autonomy and it is a stressful aspect of their relationships with their fathers. Gender stereotypes, which seem to be inherent in their fathers' attitudes and the images of their daughters, are the reason for these difficulties.

In these essays the fathers are described as powerful men. The authors use phrases such as "the head of the family or a unique figure". These fathers do not 
express their feelings or show their affections. Their attitudes are not subject to modification or negotiation.

The authors of essays 2 and 3 are aware of the rigid and patriarchal structures within their families, but at the same time they do not see any chance to change these situations. Any attempt to change them leads to conflicts and causes emotional distance between the daughter and her father.

\section{Discussion}

The authors describe daughter-father relationships from their particular perspective. It is a perspective of young women who come from patriarchal families. In these families, as these essays show, daughters are less powerful than their fathers. It is a father who is a dominant figure. The daughter - both as a child and a woman - is in a subordinate position. She is treated like a child, not like an adult. The father does not understand the change his daughter has experienced by becoming a woman, he does not support her and is emotionally distant. The daughter does not have the authority, power or resources to change the system of relationships in the family. She is stuck with a sense of confusion and ambivalent feelings toward her father. Eventually, the way to become a decision-making person is to break the relationship with her father (essay 1).

According to standpoint theories those who are less powerful are often more objective/reliable in their accounts than the standpoints of those who are more powerful. The focus on daughters' standpoints reveals the voices of women who are devoid of power within their families, in everyday life.

The topic of the essay - the women's perception of daughter-father relationship - is difficult for several reasons. It is difficult because it is not a topic that is undertaken in everyday thinking. The biographical knowledge is a result of reflective, intellectual work. It requires to make oneself an object of the self-examination. Writing an essay inspired the authors' reflexivity - they had to recognize their relationships with their fathers and describe them. Reflexivity is an important factor that induces self-knowledge and knowledge about family relations. Such knowledge has the emancipatory potential as well as pedagogical and psychological values.

\section{References}

Alexander I. (1989) A Conversation On Studying And Writing About Women's Lives Using Nontraditional Methodologies, “Women's Studies Quarterly", 17 (3-4): 99-114.

Appelrouth S. Edles L. D. (2008) Classical and Contemporary Sociological Theory: Text and Readings, Los Angeles, London, New Delhi, Singapore, Pine Forge Press. 
Collins Hill P. (1990) Black Feminist Thought: Knowledge, Consciousness and the Politics of Empowerment, Boston, Unwin Hyman.

Collins Hill P. (2004) Learning from the Outsider With in: The Sociological Significance of Black Feminist Thought in: The Feminist Standpoint Theory Reader, S. Harding (ed.), New York, Routledge.

Collins Hill P. (2005), Some Group Matters: Intersectionality, Situated Standpoints, and Black Feminist Thought in: A Companion to African-American Philosophy, T. L. Lott, J. P. Pittman (eds.), Blackwell Publishing.

Haraway D. (1988) Situated Knowledges: The Science Question in Feminism and the Privilege of Partial Perspective, "Feminist Studies", 14 (3): 575-599, http://www. staff.amu.edu.pl/ ewa/Haraway,\%20Situated\%20Knowledges.pdf

Harding S. (1987) Conclusion. Epistemological Questions in: Feminism and Methodology. Social Science Issues, S. Harding (ed.), Bloomington and Indianapolis, Indiana University Press: 181-189.

Harding S. (1991) Whose Science? Whose Knowledge? Thinking from Women's Lives, New York, Open University Press.

Intermann K. (2010) 25 Years of Feminist Empiricism and Standpoint Theory: Where Are We Now? "Hypatia”, 25 (4): 778-796.

Maynard M. (1995) Feminist Social Research, „Kwartalnik Pedagogiczny” [The Pedagogical Quarterly], 1-2 (155-156): 97-117.

Olesen V. (2005) Early Millennial Feminist Qualitative Research: Challenges and Contours in: The Sage Handbook of Qualitative Research, N. K. Denzin, Y. S. Lincoln (eds.), (3rd ed.): 235-278, Thousand Oaks, Sage Publications.

Smith D. (1987), The Everyday World as Problematic: A Feminist Sociology, Boston, Northeastern University Press.

Smith D. (1990) The Conceptual Practices of Power: A Feminist Sociology of Knowledge, Toronto, University of Toronto Press.

Smith D. (2005) Institutional Ethnography: A Sociology for People, Toronto, AltaMira Press. 